\title{
Drying and Rehydration of Oyster Mushroom
}

\author{
Giannini Pasiznick Apati ${ }^{1,2}$, Sandra Aparecida Furlan ${ }^{1 *}$ and João Borges Laurindo ${ }^{2}$ \\ ${ }^{1}$ Universidade da Região de Joinville; Campus Universitário, s/n,; 89223-251; Joinville - SC - Brasil. \\ ${ }^{2}$ Universidade Federal de Santa Catarina; C. P.: 476; 88040-900; Florianópolis - SC - Brasil
}

\begin{abstract}
Dehydration and rehydration processes of Pleurotus ostreatus fruiting bodies were investigated in this work. Mushroom samples were dehydrated at 40, 50 and $60{ }^{\circ} \mathrm{C}$, using drying air with relative humidity of $75 \%$. The rehydration was investigated at different temperatures of immersion water $\left(25,55\right.$ and $\left.85{ }^{\circ} \mathrm{C}\right)$ and different immersion times (30, 75 and 120 minutes). The best rehydration occurred for the samples dried at $40^{\circ} \mathrm{C}$. The rehydration could be done in water at room temperature, during 30 minutes. Water sorption isotherms of samples were determined at 30,40 and $50^{\circ} \mathrm{C}$. Both $\mathrm{GAB}$ and BET models satisfactorily represented the experimental data of moisture sorption of dried mushrooms.
\end{abstract}

Key words: Pleurotus ostreatus, dehydration, rehydration, moisture sorption isotherms

\section{INTRODUCTION}

Large amounts of wastes are generated by the agricultural sector, forest exploitation and food industries, which are treated or sent to sanitary landfills. Searching the equilibrium between the social, economic and environmental aspects, the reuse of agricultural wastes has taken on an extremely important dual purpose: elimination or reduction of wastes from the environment and giving them added value through the production of low cost food (Villas-Bôas et al., 2002). One of the strategies developed for the disposal of large amounts of lignocellulosic wastes is the production of edible mushrooms (Chang and Miles, 1992). Recent studies have employed agricultural and forest wastes to optimize the biological, chemical and physical parameters for mushroom cultivation (Leifa, 2002; Chaves, et al., 2004; Gern, 2005; Furlan et al., 2006).
Pleurotus spp., commonly known as oyster fungi, is a common primary degrader of wood and vegetable residues (Zadrazil and Kurtzman, 1981). It can be found in tropical and subtropical regions and in rainforests, and can also be artificially cultivated (Maziero et al., 1992). Appreciated because of its delicious taste, these fungi contain high quantities of proteins and carbohydrates, minerals (calcium, phosphorus, iron, etc), and vitamins (thiamin, riboflavin and niacin) as well as low fat content (Sturion and Oetterer, 1995; Justo et al., 1998; Manzi et al., 1999). According to Silveira et al. (2006), the energy values of $P$. ostreatus DSM 1833 is between 139.36 and $213.05 \mathrm{kcal} / 100 \mathrm{~g}$ of mushrooms.

For many reasons, the fungi of Pleurotus genus have been intensively studied in many different parts of the world: high gastronomic value, ability to colonize and degrade a large variety of lignocellulosic residues, shorter growth time when

*Author for correspondence: sfurlan@univille.br 
compared to other edible mushrooms; little environmental control, few diseases and pests attack fruiting bodies, simple and cheap cultivation technique (Jwanny et al., 1995; Patrabansh and Madan, 1997).

The mushrooms of the Pleurotus genus are more delicate and sensitive than the Agaricus genus and they start deteriorating immediately within one day after the harvest. Once deteriorated, these fruiting bodies can cause severe gastrointestinal discomfort. Under ideal climatic conditions, shelf life of these mushrooms is about 10 days, their quality being affected predominantly by storage temperature. The shelf life can be reduced from 9 days at $2{ }^{\circ} \mathrm{C}$ to 3 days at $18{ }^{\circ} \mathrm{C}$ (Lukasse and Polderdijk, 2003). Therefore, cooling the fresh mushrooms can be an alternative regarding their distribution and sale, thus increasing their shelf life (Villaescusa and Gil, 2003). For long periods of conservation, the traditionally used method for Pleurotus genus mushrooms is the convective drying at $45-65^{\circ} \mathrm{C}$ (Pal and Chakraverty, 1997; Arora et al., 2003). Dehydration is a classical method of food conservation, based on the principle that the reduction of the water activity of the product must be conducted until defined levels that guarantee the microbiological and physicochemical stability (Cao et al., 2003; Krokida et al., 2003; Lewicki and Jakubczyk, 2004).

The dehydrated mushrooms can be rehydrated by water immersion before the consumption. The rehydration characteristics of dried products are used as a quality parameter and indicate if physical and chemical changes occurred during the drying process due to process conditions, pre-treatments and sample composition (Funebo and Ohlsson, 1998; Lewicki, 1998). Funebo and Ohlsson (1998) studied the rehydration capacity of Agaricus bisporus fruiting bodies after hot-air dehydration, followed or not by microwave at the end of the dehydration process. The power of the applied microwaves was measured through the temperature of the food center. Rehydration capacity was better using hot-air dehydration without the use of microwaves.

Based on the above discussion, this work dealt with the evaluation of a conservation process for Pleurotus ostreatus fruiting bodies. Mushroom dehydration was performed in an oven with forced air circulation and their rehydration capacity was investigated. Due to their importance in food storage, water sorption isotherms were determined for fresh whole mushrooms, dehydrated mushrooms and powdered dehydrated mushrooms.

\section{MATERIALS AND METHODS}

\section{Microorganism and maintenance}

$P$. ostreatus DSM 1833, was used in this work. The culture was kept in Petri dishes containing WDA medium $(1 \mathrm{~L}$ of wheat extract, $20 \mathrm{~g}$ of dextrose and $15 \mathrm{~g}$ of agar) at $4{ }^{\circ} \mathrm{C}$. The wheat grains were washed and cooked in boiling deionised water for $10 \mathrm{~min}$ at a ratio of 1:2 (wheat grain mass: water volume), then the liquid drained were used as a wheat extract (Furlan et al., 1997).

\section{Inoculum production (spawn)}

Wheat grains were used as substrate and growth support. The cooked grains, obtained as described above were supplemented with $0.35 \%$ of calcium carbonate and $1.3 \%$ of calcium sulphate (dry mass basis) and then packed $(250 \mathrm{~g})$ in polypropylene (PP) bags $(18 \times 30 \mathrm{~cm})$. The bags were sterilized at $121{ }^{\circ} \mathrm{C}$ for $1 \mathrm{~h}$, cooled to room temperature and inoculated with three $15 \mathrm{~mm}$ diameter agar disks containing the Pleurotus mycelium taken from the Petri dishes. The bags were incubated at $30{ }^{\circ} \mathrm{C}$, in the absence of light, for 15 days or until complete colonization of the grain surfaces by the mycelium. The bags containing the solid inoculum were kept for three months at $4^{\circ} \mathrm{C}$ for further use.

\section{Culture medium and environmental conditions for fruiting body formation}

Banana straw, consisting of banana plant leaves, was used as cultivation substrate. The banana straw were ground into 2 to $5 \mathrm{~cm}$ particles, dried at $60{ }^{\circ} \mathrm{C}$ for $1 \mathrm{~h}$ and packed in raffia bags. The bags containing the straw were kept under immersion in water for $12 \mathrm{~h}$ according to Madan et al. (1987). Afterwards, $150 \mathrm{~g}$ (dry weight) of the substrate were transferred to transparent PP bags $(50 \mu$ thick). The substrate was supplemented with $5 \%$ of rice bran (dry weight), closed, sterilized in an autoclave at $121{ }^{\circ} \mathrm{C}$ for $1 \mathrm{~h}$, cooled to environmental temperature under UV radiation for 30 minutes, inoculated with $10 \%$ (dry weight) spawn and homogenized. The bags were incubated at $30^{\circ} \mathrm{C}$ until total colonization. The bags were transferred to the cultivation room $\left(24 \mathrm{~m}^{2}\right)$ for fruiting body production $\left(27^{\circ} \mathrm{C}\right.$, light deviation between 500 and 1000 lux, $12 \mathrm{~h}$ a day, and air 
humidity equal to $88 \%$ were automatically controlled and the air exchange was ensured by air conditioning). Primordia were induced by making small perforations in the bags. Fruiting bodies were harvested with a scalpel as described by Sturion (1994).

\section{Drying}

After harvest, $50 \mathrm{~g}$ of mushrooms were dehydrated in an oven with forced air circulation at 40,50 and $60{ }^{\circ} \mathrm{C}$ and relative air humidity of $75 \%$. The samples were placed in Petri dishes and hanged to a weighing apparatus, to determine the drying curves. The sample mass was registered each 15 minutes. The determination of the sample humidity was carried out by weighing the samples before and after drying at $90{ }^{\circ} \mathrm{C}$ for $48 \mathrm{~h}$ (gravimetric method).

\section{Rehydration}

The rehydration parameters were evaluated using an experimental design $3^{3-1}$, in which the drying temperature $\left(40,50\right.$ and $\left.60^{\circ} \mathrm{C}\right)$, the water immersion temperature $\left(25,55\right.$ and $\left.85^{\circ} \mathrm{C}\right)$ and the water immersion time (30, 75 and 120 minutes) were the investigated variables. This resulted in nine experiments, which were carried out in duplicate. In each experiment $2.0 \mathrm{~g}$ dried mushroom were immersed in $100 \mathrm{~mL}$ of water. After rehydration, excess water was drained, the samples dried with absorbent paper and weighed again.

\section{Water sorption isotherms}

Water sorption isotherm experiments were performed at 30,40 and $50{ }^{\circ} \mathrm{C}$ for mushrooms fresh, dehydrated mushrooms and powdered dehydrated mushrooms, using the saline solutions static method (Rizvi, 1986). Two grams of sample were placed in porcelain crucibles kept in desiccator and periodically weighed until constant weight. After 25 days, the mushrooms reached equilibrium. The GAB (Guggenheim, Anderson and De Boer) and BET (Brunauer, Emmett and Teller) models, given by equations 1 and 2 , respectively, were used to represent the experimental isotherms. The models' parameters were determined by a non-linear regression, using the software Statistica $^{\circledR} \quad 6.0$ for Windows ${ }^{\circledR}$ (Statsoft, Tulusa, UK).

$$
\begin{aligned}
& \frac{X_{e}}{X_{m}}=\frac{C K a_{w}}{\left(1-a_{w}\right)\left(1-K a_{w}+C K a_{w}\right)} \\
& \frac{X_{e}}{X_{m}}=\frac{C a_{w}}{\left(1-a_{w}\right)\left(1-a_{w}+C a_{w}\right)}
\end{aligned}
$$

where, $a_{w}$ is the water activity, $X_{m}$ is the value of the monolayer moisture in dry basis $(\mathrm{gw} / \mathrm{g}), \mathrm{C}$ is the sorption heat related to the adsorbed monolayer, $\mathrm{K}$ is the sorption heat related to the multilayers and $X_{e}$ represents the equilibrium moisture, in dry basis.

\section{Statistical analysis}

The drying tests were carried out in triplicate and the mean values and standard errors were calculated using the software Origin ${ }^{\circledR} 7.0$. In order to investigate the parameters that influenced the rehydration process, the software Statistica ${ }^{\circledR} 6.0$ was used to the Pareto analysis with 5\% significance level.

\section{RESULTS AND DISCUSSIONS}

\section{Drying}

Figure 1 (a) presents the drying curves for $P$. ostreatus fruiting bodies. The curves' slopes indicate the presence of a small drying period at constant rate, at the beginning of the process. It was better observed in the drying rate curves (Fig. 1b). The duration of constant rate were about 65 minutes at $40{ }^{\circ} \mathrm{C}, 35$ minutes at $50{ }^{\circ} \mathrm{C}$ and 25 minutes at $60^{\circ} \mathrm{C}$. Martínez-Soto et al. (2001) had also observed a very small period of constant drying rate (5 minutes) during $P$. ostreatus fruiting body drying. However, some authors have not observed the existence of a constant rate period during dehydration of $P$. florida (Arora et al., 2003). As expected, an increase in the drying speed with the increase of drying temperature was observed. This implied in a reduction of $43.7 \%$ in the process time when the drying temperature changed from 40 to $60{ }^{\circ} \mathrm{C}$ and a reduction of $28.6 \%$ when the temperature changed from 50 to $60{ }^{\circ} \mathrm{C}$. Similar results have been found in the literature (Arora et al., 2003; Krokida et al., 2003) for A. bisporus and P. florida fruiting body drying. Pal and Chakraverty (1997) found reduction of 
about $40 \%$ in the process time, when the drying temperature of $P$. ostreatus fruiting bodies was increased from 45 to $60^{\circ} \mathrm{C}$. The visual quality of the dehydrated mushrooms was not affected by the drying temperatures investigated in this work.

\section{Rehydration}

For mushrooms, besides the investigation of the drying times and rates, the product rehydration capacity and quality should also be evaluated. Figure 2 presents the visual comparison between fresh, dehydrated and rehydrated mushrooms. It was observed that the rehydrated mushrooms had good appearance, even so they did not recover the same appearance of fresh mushrooms, because they were not completely rehydrated and suffered some changes under the drying conditions. According to Pareto charts presented in Figure 3, the rehydration capacity was related to the drying temperature, which presented significant effects. The immersion time in water and the water rehydration temperature did not present a significant influence on the fruiting body rehydration capacity. However, the drying temperature increase had a negative influence on the fruiting body rehydration capacity. The rehydration capacity decreased with increasing drying temperature, which could be associated to the stronger mushroom structure deformation at higher temperatures. According to Foust et al. (1982), increasing drying temperature leads to the increase of water liberation rate, then promoting important structure deformations in the biological material. Thus, considering the rehydration performance, the lower drying temperature $\left(40{ }^{\circ} \mathrm{C}\right)$ could be suggested for Pleurotus dehydration.

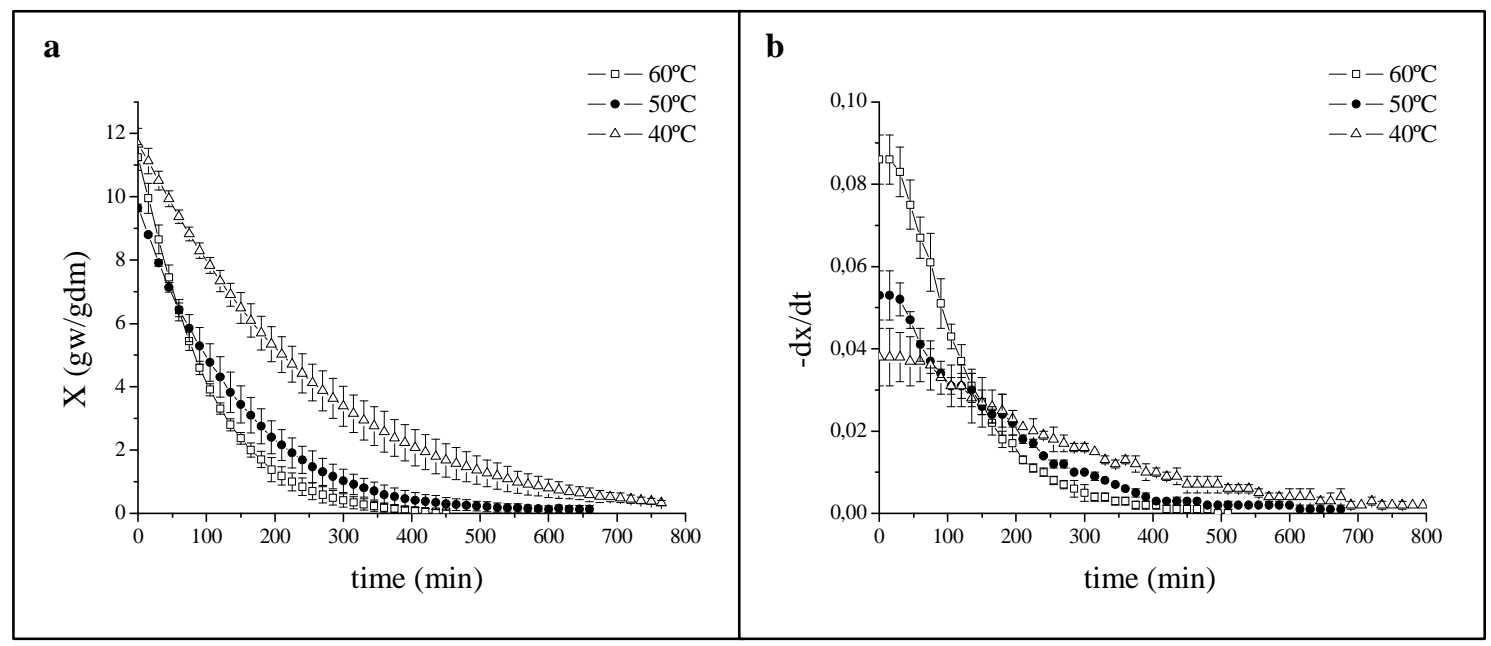

Figure 1 - (a) Drying curves of fruiting bodies of Pleurotus ostreatus DSM 1833, at the temperatures of 40,50 and $60^{\circ} \mathrm{C}$ and relative humidity at $75 \%$, (b) Drying rate of Pleurotus ostreatus $(-\mathrm{dX} / \mathrm{dt})$ as a time function $(\mathrm{t}),[\mathrm{X}=$ water content, in grams of water / grams of dry matter (gw/gdm) $]$.

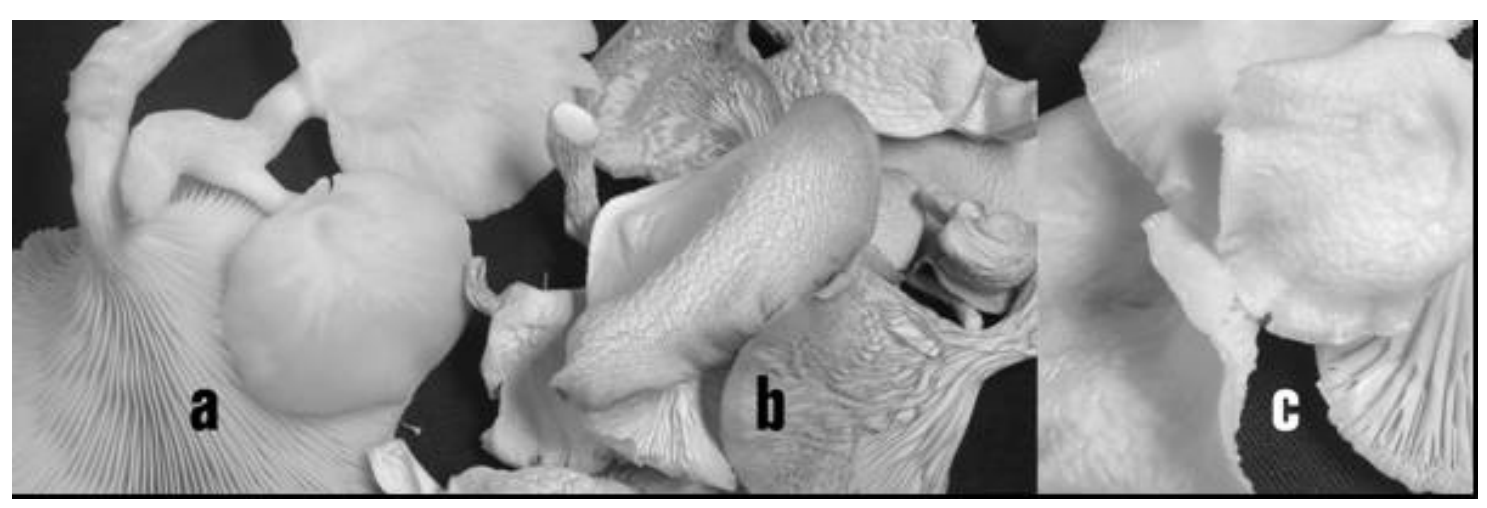

Figure 2 - Fruiting bodies of P. ostreatus DSM 1833: (a) fresh, (b) dehydrated and (c) rehydrated. 


\section{Water sorption isotherms}

The parameters of GAB and BET models for 30 , 40 and $50^{\circ} \mathrm{C}$, as well as the correlation coefficients (R), are given in the Table 1. Both models represented satisfactorily the experimental data of moisture sorption. It was observed that $\mathrm{K}$ values in the GAB model had always been very near to 1 , which could make this model equivalent to BET model. There are no reports in the literature, concerning the use of BET model for mushroom sorption isotherms. However, Belarbi et al. (2000), testing GAB and BET models for several date species, observed that in some cases, the BET model could represent the experimental data as well as GAB model.

Figure 4 presents sorption isotherms obtained at 30,40 and $50{ }^{\circ} \mathrm{C}$. The equilibrium humidity decreased with the increase of temperature. This was because the kinetic energy associated with the molecules of water present in the food increased with increasing temperature (Shivhare et al., 2004). At high water activities, this was no longer be observed. Significant differences in the equilibrium humidity of fresh, dehydrated and powdered dehydrated mushrooms were not observed, independent of the temperature used.

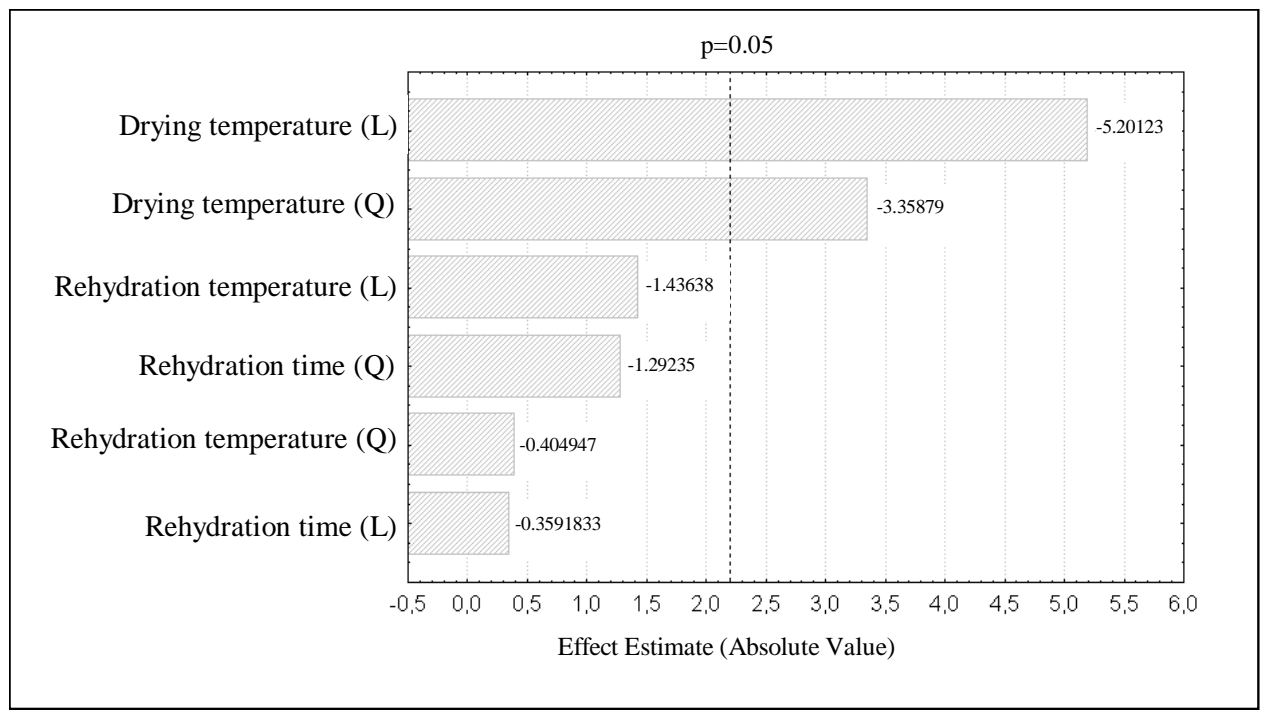

Figure 3 - Pareto charts to the rehydration capacity parameters of $P$. ostreatus specie mushrooms ( $\mathrm{L}=$ linear model; $\mathrm{Q}=$ quadratic model).

Table 1 - GAB and BET constants for the water sorption isotherms modeling to mushrooms $\left[a_{w}=\right.$ water activity, $\mathrm{X}_{\mathrm{m}}=$ value of the monolayer $(\mathrm{gw} / \mathrm{gdm}), \mathrm{C}=$ sorption constant, $\mathrm{K}=$ correction factor and $\mathrm{X}_{\mathrm{e}}=$ equilibrium humidity (gw/gdm)].

\begin{tabular}{lcccccccc} 
& & \multicolumn{9}{c}{$\mathbf{G A B}$} & \multicolumn{3}{c}{ BET } \\
\cline { 2 - 9 } & $\mathbf{T}\left({ }^{\mathbf{0}} \mathbf{C}\right)$ & $\begin{array}{c}\mathbf{X}_{\mathbf{m}} \\
\text { (gw/gdm) }\end{array}$ & $\mathbf{C}$ & $\mathbf{K}$ & $\mathbf{R}$ & $\begin{array}{c}\mathbf{X}_{\mathbf{m}} \\
\text { (gw/gdm) }\end{array}$ & $\mathbf{C}$ & $\mathbf{R}$ \\
\hline \multirow{2}{*}{ "fresh" } & 30 & 0.1006 & 0.0305 & 1.0056 & 0.9877 & 0.1592 & 0.0456 & 0.9869 \\
mushrooms & 40 & 0.1526 & 0.0444 & 1.0166 & 0.9971 & 0.2353 & 0.0675 & 0.9063 \\
& 50 & 0.1173 & 0.0244 & 0.9859 & 0.9264 & 0.1610 & 0.0312 & 0.9285 \\
\hline \multirow{2}{*}{ Dried } & 30 & 0.1307 & 0.0341 & 1.0047 & 0.9921 & 0.1876 & 0.0468 & 0.9916 \\
mushrooms & 40 & 0.3304 & 0.0796 & 0.9966 & 0.9937 & 0.2539 & 0.0641 & 0.9935 \\
& 50 & 0.2208 & 0.0374 & 1.0139 & 0.9967 & 0.3437 & 0.0562 & 0.9689 \\
\hline Dried and & 30 & 0.1507 & 0.0403 & 1.0033 & 0.9913 & 0.1955 & 0.0504 & 0.9910 \\
powdered & 40 & 0.3711 & 0.0907 & 0.9884 & 0.9899 & 0.0904 & 0.0368 & 0.9587 \\
mushrooms & 50 & 0.2189 & 0.0487 & 1.0077 & 0.9931 & 0.3172 & 0.0643 & 0.9796 \\
\hline
\end{tabular}



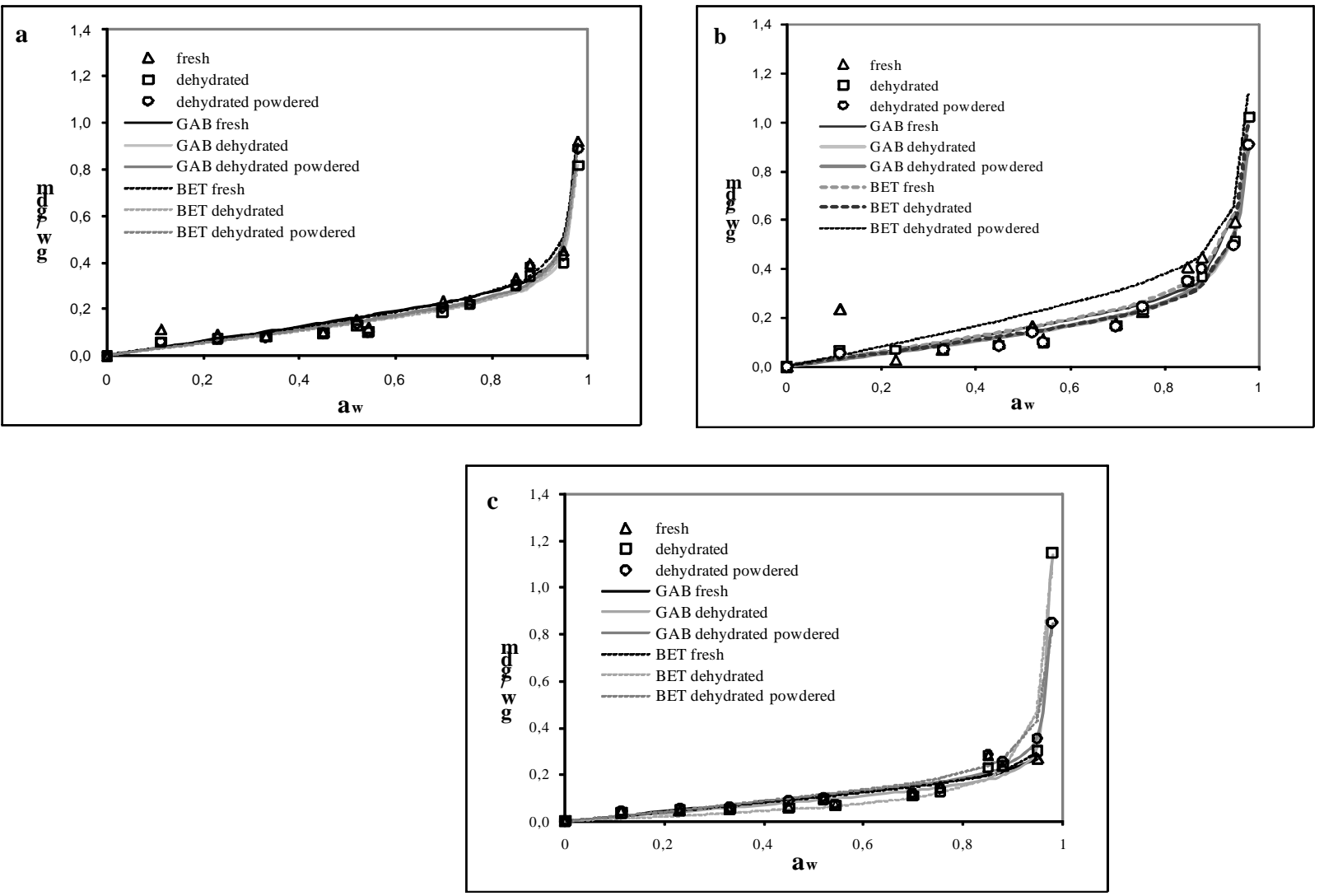

Figure 4 - Water sorption isotherms at $30{ }^{\circ} \mathrm{C}(\mathrm{a}), 40{ }^{\circ} \mathrm{C}(\mathrm{b})$ and $50{ }^{\circ} \mathrm{C}$ (c) for the fruiting bodies of P. ostreatus DSM $1833\left(\mathrm{a}_{\mathrm{w}}=\right.$ water activity and $\mathrm{gw} / \mathrm{gdm}=$ grams of water $/$ grams of dry matter).

\section{CONCLUSIONS}

The drying temperature is a very important process variable in mushroom drying. The best temperature for $P$. ostreatus fruiting bodies drying process was $40{ }^{\circ} \mathrm{C}$, taking into consideration the best rehydration of the fruiting bodies dried at this temperature. The rehydration could be done in water at room temperature during 30 minutes. Both GAB and BET models represented satisfactorily the experimental data of moisture sorption.

\section{ACKNOWLEDGEMENTS}

Giannini Pasiznick Apati would like to thank CAPES/Acafe for the financial support. João Borges Laurindo thanks $\mathrm{CNPq}$ for $\mathrm{PQ}$ research scholarship.

\section{RESUMO}

Processos de desidratação e de rehidratação de cogumelos da espécie Pleurotus ostreatus foram avaliados neste trabalho. Os cogumelos foram desidratados a 40,50 e $60^{\circ} \mathrm{C}$, com umidade relativa do ar de $75 \%$. O processo de rehidratação foi avaliado para diferentes temperaturas de água de imersão $\left(25,55\right.$ e $\left.85^{\circ} \mathrm{C}\right)$ e diferentes tempos de imersão (30, 75 e 120 minutos). A melhor temperatura de secagem foi $40^{\circ} \mathrm{C}$, levando em consideração a melhor rehidratação dos cogumelos desidratados nesta temperatura. A rehidratação pode ser feita em água a temperatura ambiente, por 30 minutos. Isotermas de sorção de umidade de amostras foram determinadas a 30,40 e $50{ }^{\circ} \mathrm{C}$.Tanto o modelo de GAB quanto o de BET representaram satisfatoriamente os dados experimentais de isoterma de sorção de umidade. 


\section{REFERENCES}

Arora, S.; Shivhare, U.S.; Ahmed, J.; Raghavan, G.S.V. (2003), Drying kinetics of Agaricus bisporus and Pleurotus florida mushrooms. Amer. Soc. of Agricult. Eng., 46, 721-724.

Belarbi, A.; Aymard, C.H.; Meot, J.M.; Themelin, A.; Reynes, M. (2000), Water desorption isotherms for eleven varieties of dates. J. Food Eng., 43, 103-107.

Cao, W.; Nishiyama, Y.; Koide, S. (2003), Thin-layer drying of Maitake Mushroom analysed with a simplified model. Biosys. Eng., 85, 331-337.

Chang, S.T.; Miles, P.G. (1992), Recent trends in world production of cultivated edible mushrooms. Mushroom J. Internat. Scie., p. 15-18.

Chaves, M.B.; Karnopp, P.; Soares, H.M.; Furlan, S.A. (2004). Evaluation of Pleurotus ostreatus and Pleurotus sajor caju nutricional characteristics when cultivated in different lignocellulosic wastes. Food Chemistry, 88 (3), 425-428.

Foust, A.S.; Wenzel, L.A.; Clump, C.W.; Maus, L.; Andersen. L.B. (1982), Princípio das operações unitárias. Editora AS, Rio de Janeiro, $2^{\mathrm{a}}$ ed., 670p.

Funebo, T.; Ohlsson, T. (1998), Microwave-assisted Air Dehydration of Apple and Mushroom. J. Food Eng., 38, 353-367.

Furlan, S. A.; Virmond, L. J.; Miers, D. A.; Bonatti, M.; Gern, R. M. M.; Jonas, R. (1997), Mushroom strains able to grow at high temperatures and low $\mathrm{pH}$ values. World J Microbiol. Biotechnol., 13, 689-692.

Furlan, S.A.; Gern, R.M.M.; Wisbeck, E.; Bonatti, M.; Silveira, M.L.L.; Da Silva, H.H. (2006), Possibilities of Pleurotus applications in food, health and environmental technologies. In: Proccedings of the $2^{\text {nd }}$ International Congress on Bioprocesses in Food industries, ICBF, Patras:Greece, p. 34-35.

Gern, R.M.M. (2005), Estudo de meios de cultivo para produção de biomassa e polissacarídeos por Pleurotus ostreatus DSM 1833 em cultivo submerso. 137 p. Thesis (Doctor in Chemical Engineering), Universidade Federal de Santa Catarina, Florianópolis, Brazil.

Justo, M. B.; Guzmán, G. A.; Mejía, E. G.; Díaz, C. L. G.; Martínez, G.; Corona, E. B. (1998), Composition química de tres cepas mexicanas de setas (Pleurotus ostreatus). Archivos Latinoamericanos de Nutricion, 48 (4), 359-363.

Jwanny, E. W.; Rashad, M. M.; Abdu, H. M. (1995). Solid-state fermentation of agricultural wastes into food through Pleurotus cultivation. Appl. Biochem. and Biotechnol., 50 (1) 71-78.

Krokida, M.K.; Karathanos. V.T.; Maroulis, Z.B.; Marinos-Kouris. D. (2003). Drying kinetics of some vegetables. J. Food Eng., 59, 391-403.
Leifa, F. (2002). Production of extra-cellular polysaccharide from Agaricus blasei by submerged and solid state culture and its antitumor effect. $123 \mathrm{p}$. Thesis (Doctor in Biothecnology Process), Universidade Federal do Paraná, Curitiba, Brazil.

Lewicki, P.P. (1998), Some Remarks on Rehydration of Dried Foods. J. Food Eng., 36, 81-87.

Lewicki, P.P.; Jakubczyk, E. (2004), Effect of hot air temperature on mechanical properties of dried apples. J. Food Eng., 64, 307-314.

Lukasse, L.J.S.; Polderdijk, J.J. (2003), Predictive modelling of post-harvest quality evolution in perishables, applied to mushrooms. J. Food Eng., 59, 191-198.

Madan, M.; Vasudevan, P.; Sharma, S. (1987), Cultivation of Pleurotus sajor-caju on different wastes. Biological Wastes, 22 (4), 241-250.

Manzi, P.; Gambelli, L.; Marconi, S.; Vivanti, V.; Pizzoferrato, L. (1999), Nutrients in edible mushrooms: an inter-species comparative study. Food Chemistry, 65 (4),.477-482.

Martínez-Soto, G.; Ocanã-Camacho, R.; ParedesLópez, O. (2001). Effect of pretreatment and drying on the quality of oyster mushroom (Pleurotus osteratus). Drying Technol., 19,. 661-672.

Maziero, R.; Bononi, V. L.; Capelari, M. (1992), Cultivo e produtividade de Pleurotus ostreatus var. florida em Mogi das Cruzes, SP, Brasil. Hoehnea, São Paulo.

Pal, U.S.; Chakraverty, A. (1997), Thin Layer Convection-Drying of Mushrooms. Energy Convers. Manag., 38 (2), 107-113.

Patrabansh, S.; Madan, M. (1997), Studies on cultivation, biological efficiency and chemical analysis of Pleurotus sajor-caju (FR.) Singer on different bio-wastes. Acta Biotechnology, 17 (2), p.107-122.

Rizvi, S.S.H. (1986), Thermodynamics of food in dehydration. In Rao, M.A; Rizvi, S.S.H. Engineering properties of foods. Marcel Dekker, New York, p.133-214.

Shivhare, U.S.; Arora, S.; Ahmed, J.; Raghavan, G.S.V. (2004). Moisture adsorption isotherms for mushroom. Lebensmittel-Wissenschaft und -Technologie, 37, 133-137.

Silveira, M.L.L.; Bonatti, M.; Karnopp, P.; Ninow, J.L.; Furlan, S.A. (2006) Evaluation of inoculum influence on Pleurotus nutritional characteristics. Braz. Arch. Biol. Technol., 49, 85-90.

Sturion, G. L. (1994), Utilização da folha de bananeira como substrato para o cultivo de cogumelos comestíveis (Pleurotus spp.). Dissertation (Master's degree in Food Science). Universidade de São Paulo, São Paulo, Brazil. 
Sturion, G. L.; Oetterer, M. (1995), Composição química de cogumelos comestíveis (Pleurotus spp.) originados de cultivos em diferentes substratos. Ciênc. Tecnol. Aliment., 15 (2), 189-193.

Villaescusa, R.; Gil, M.I. (2003), Quality improvement of Pleurotus mushrooms by modified atmosphere packaging and moisture absorbers. Postharvest Biol. Technol., 28, 169-179.

Villas-Bôas, S.G.; Esposito, E.; Mitchell, D.A. (2002), Microbial conversion of lignocellulosic residues for production of animal feeds. Animal Feed Scie. Technol., 98, 1-12.
Zadrazil, F.; Kurtzman, R. H. (1981), The biology of Pleurotus cultivation in the tropics. In: Chang, S. T., Quimio, T. H. Tropical Mushrooms. The Chinese Univ. Press, Shatin, Hong Kong, pp. 493.

Received: March 17, 2008; Revised: February 12, 2009; Accepted: October 01, 2009. 